\title{
РОЛЬ «ЗАБАВ ПРИ МЕРЩ» В РИТУАЛЬНОМУ ПРОЦЕСІ ПОХОРОНУ У ГУЦУЛІВ
}

Анотація: У статті, на основі етнографічних описів кіния XIX - першої половини XX $\mathrm{cm}$. та наявної історіографії, проаналізовано значення «забав при мериі» у контексті ритуального процесу зміни статусу індивідуума під час поховального обряду. Спираючись на структурносемантичний, семіотичний і типологічний підходи, автор окреслив причини побутування уявлень про необхідність здійснення «забав при мериі» у системі ритуальної зміни стану людини. Встановлено, що ще дійство було основним елементом ритуальної драми, що базується на бінарній опозииї космос/хаос (тут і там). Забави при мериі демонстрували лімінальність осіб, які брали участь у поховальному обряді, а також - проникнення «хаосу» до звичного для людей світу.

Окрім того, описано та схарактеризовано основні види ігор, що здійснювалися під час похоронів, виділено їх типологічний поділ відносно семантичного навантаження, проаналізовано основні маркери локусу та дійових осіб ритуального процесу: нічна пора доби, перебування в окремих приміщеннях, антиповедінка, травестія, побиття, сліпота.

Ключові слова: ритуали переходу, поховальна обрядовість, забави при мериі, посиженіє, грушка, гущули

Разом 3 народженням, ініціацією та весіллям, похорони є частиною ритуального життєвого шляху людини. Не дивно, що поховальна обрядовість є одним з головних елементів традиційної духовної культури як української традиційної культури у цілому, так і гуцулів зокрема. Ритуали, пов'язані зі смертю людини, завжди викликають великий інтерес для етнологів, етнографів і фольклористів, адже містять у своїй суті унікальні культурні та психологічні особливості світосприйняття.

Поховальна обрядовість відноситься до так званих ритуалів переходу. Вони мають однакову структуру та здійснюються з метою наділити особу її новим статусом. У випадку зі смертю людини - здійснити правильний перехід зі стану «живих» у розряд «покійників». У ритуальному процесі це зображувалося втратою попередніх характеристик і набуття нових. Інструментами таких змін були окремі обрядодії, які тільки у своїй синергії давали необхідний результат.

Серед таких функціональних обрядодій у поховальній обрядовості гуцулів виділяються так звані «забави при мерці». Ще 3 XIX ст. українські та закордонні дослідники присвячували цьому явищу свої розвідки й описи. Водночас сьогодні в українській етнологічній науці проблема значення ігор, в які грали під час поховального

\footnotetext{
* Зубик Любомир Володимирович - аспірант кафедри етнології і археології Прикарпатського національного університету імені Василя Стефаника (Івано-Франківськ, Україна); ORCID: https://orcid.org/0000-0001-5626-6121; e-mail: lubchyk1996@gmail.com
} 
ритуалу, є малодослідженим. У науковій літературі й досі необхідність виконання таких обрядодій часто пояснюється цитатою з класичної книги В. Шухевича «Гуцульщина», в якій при описі «забав при мерці» вказано відгук одного з учасників ігор: «...ми це робимо аби рідним не було тяжко, самим, аби ніхто не спав коло мерця...», або ж узагальненням цієї цитати. Саме тому питання ролі «забав при мерці» під час поховального обряду потребує детального вивчення крізь призму переходової ритуалістики.

Мета і завдання. На сьогодні в українській історіографії практично відсутні спеціальні дослідження, присвячені ролі «забав при мерці» у поховальній обрядовості гуцулів. Тому метою цієї розвідки є спроба з'ясувати обрядове значення «забав при мерці». Завдання вбачаємо в аналізі відомих ігор, визначенні їх семантики та ролі у ритуальному тексті поховального обряду.

Аналіз основних досліджень. Ігри при померлому стали об’єктом дослідження науковців наприкінці XIX ст. Детальний опис понад двадцяти забав знаходимо у третьому томі класичної праці українського етнографа Володимира Шухевича «Гуцульщина». Кожна з них є детально описаною, в окремих випадках вказано дві форми назви тієі чи іншої гри. Також понад 20 описів ігор при померлому знаходимо в працях гуцульського громадсько-політичного діяча, етнографа та письменника Петра Шекерика-Дониківа. Найбільшу цінність для нас має його праця «Похоронні звичаї й обряди в Головах» ${ }^{2}$, де автор дає детальну характеристику кожній із забав та описує ігровий процес. Вже більш у художній формі знаходимо розповідь про ритуальне дійство у його книзі «Дідо Иванчик» ${ }^{3}$.

«Забави при мерці» стали предметом окремого дослідження українського етнографа, фольклориста, громадського діяча Володимира Гнатюка. у своїй праці «Похоронні звичаї та обряди» ${ }^{4}$ він подає докладний опис ігор під час «посижіння» в селі Зелениця Надвірнянського повіту, селі Жабє-Магурі Косівського повіту, а також помістив вже згадану працю П. Шекерика-Дониківа.

Завдяки розлогим дослідженням «забав при мерці» на Гуцульщині, окрему увагу у праці «Посижінє і забави при мерци в українськім похороннім обряді» український мовознавець, фольклорист, етнограф Зенон Кузеля. У ній він на підставі аналізу доступних джерел виділив причини появи й наступну трансформацію ігор при померлому, окреслив території поширення цього звичаю в Україні та поза ії межами, здійснив аналіз причин побутування та занепаду цього дійства.

у радянський період тематика «забав при мерці» не знайшла відгуку серед дослідників гуцулів. Короткі відомості про них хіба можемо знайти у монографії «Гуцульщина. І Історико-етнографічне дослідження» ${ }^{6}$ та у діаспорному виданні українського дослідника Миколи Домашевського «Історія Гуцульщини». Проте вже в

\footnotetext{
${ }^{1}$ Шухевич В.О. Гуцульщина. Ч. ІІІ. Репринтне видання. Харків: Фоліо, 2019. 271 с.

${ }^{2}$ Шекерик-Доників П. Рік у віруваннях гуцулів: вибрані твори. Івано-Франківськ: Місто-НВ, 2009. 351 с.

${ }^{3}$ Шекерик-Доників П. Дідо Иванчік: роман. Харків: Фоліо, 2019. 484 с.

${ }^{4}$ Свєнціцький I., Гнатюк В. Похоронні голосіння. Похоронні звичаї та обряди. Репринтне видання. Харків: Фоліо, 2019. 438 с.

${ }^{5}$ Кузеля 3. Посижіне і забави при мерци в українськім похороннім обряді. Записки НТШ. Львів, 1915. Т. СХХІІ. С. 103-160.

${ }^{6}$ Гуцульщина. Історико-етнографічне дослідження. Київ: Наукова думка, 1987. 470 с.

${ }^{7}$ Домашевський М. Історія Гуцульщини. Т. 1. Чикаго, Львів: Логос, 1985. 502 с.
} 
період незалежності України, відновлення якої зумовило зростання інтересу до дослідження традиційної культури українців, ігри при померлому стали частіше фігурувати в працях науковців. У першу чергу можемо відзначити роботу етнолога Романа Гузія «Похоронна обрядовість українців Карпат» ${ }^{8}$, де він приділяє окрему увагу «забавам при мерці». У ній він аналізує причини побутування цього звичаю, характеризує види ігор та їх значення. Також аналіз побутування цих забав знаходимо у праці етнологині Валентини Сушко «Уявлення про смерть та похоронні звичаї у гуцулів» 9

У рамках дослідження регіональних особливостей поховальної обрядовості гуцулів, «забави при мерці» описані у працях українських науковців Ірини Чернеляк ${ }^{10}$ і Георгія Кожолянка ${ }^{11}$.

Виклад основного матеріалу. Ритуали переходу, за класичним визначенням французького етнолога Арнольда ван Геннепа, мають трифазову структуру, яка включає прелімінальний (виключення), лімінальний (перехід) і постлімінальний (включення) етап ${ }^{12}$. Суб'єкти й об'єкти ритуального процесу в період другої фази перебувають у невизначеному статусі, адже вони втратили ознаки попереднього стану, але ще не набули нових характеристик. У цьому контексті ті, хто здійснює перехід, стають tabula rasa, повертаючись до свого «першостану» ${ }^{13}$.

у ритуальному процесі лімінальний період, а саме втрата будь-яких ознак i характеристик, усвідомлюється як перебування в хаосі. Адже тільки повернувшись до «точки відліку», особа здатна отримати нові характеристики, вміння та знання, необхідні для нового статусу. Для зображення символіки переходу під час здійснення ритуалу люди вдавалися до дій, що були антиподом «звичайного» життя, так званої «антиповедінки»виконання дій, які порушували норми життя у «профанний» час. До антиповедінки відносяться травестія, нанесення тілесних ушкоджень, втрата ознак живої людини та інше $\mathrm{e}^{14}$. Такого роду дії здійснювалися у той час, коли люди вбачали зв'язок 3 потойбічним.

У поховальному ритуалі гуцулів лімінальний період представлений так званими «посижіннями», під час яких у хаті, де лежав померлий, збиралися люди та сиділи цілу ніч. Це дійство демонструвало розділення двох станів, де представники «нашого» світу не спали, а померлий заснув ${ }^{15}$. Складовою цієї частини поховального ритуалу були так звані «забави при мерці».

\footnotetext{
${ }^{8}$ Гузій Р. Похоронна обрядовість українців Карпат. М. Гримич (ред.). Народна культура українців: життєвий цикл людини. Т. 5. Старість. Смерть. Культура вшанування небіжчиків. Київ: Дуліби, 2015. С. 239-253.

${ }_{9}^{9}$ Сушко В. Уявлення про смерть і поховальні звичаї гуцулів. Народна творчість та етнологіл. 2014. № 1. C. 91-97.

${ }^{10}$ Чернеляк I. Поховально-поминальні обряди українців Закарпаття кінця XIX - першої половини XX ст. Записки історичного факультету. 2016. № 27. С. 197-221

${ }^{11}$ Кожолянко Г. Розваги та ігри у поховальному обряді буковинців. Питання стародавньої та середньовічної історії, археології й етнологіï. 2011. № 2. С. 138-149.

${ }^{12}$ Геннеп А. ван. Обряды перехода. Систематическое изучение обрядов. Москва: Издательская фирма «Восточная литература» РАН, 1999. 198 с.

${ }^{13}$ Тэрнер В. Символ и ритуал. Москва: Издательская фирма «Восточная литература» PAH, 1983. 277 с. URL: http://platona.net/load/knigi_po filosofii/anlropologija/lemerviktorsimvoliritual1983/5-1-0-1016

${ }^{14}$ Лисина Е.А. К вопросу о механизмах перехода: социально философский аспект. Вестник Оренбургского государственного университета. 2011. № 7 (126). С. 115-120.

${ }^{15}$ Байбурин А.К. Ритуал в традиционной культуре: структурно-семантический анализ восточнославянских обрядов. Санкт-Петербург: Наука, 1993. 240 с.
} 
Різноманітні ігри під час поховального обряду ми спостерігаємо в обрядовості хорватів, сербів, болгар, молдаван, румунів, німців та інших етносів по всьому світі ${ }^{16}$. «Забави при мерці» були поширені на всій території проживання українців, проте в кінці XIX - початку XX ст., як зазначали етнографи-сучасники, вже виходили з вжитку у зв'язку з боротьбою священників з цим ритуалом. Ці ігри здійснювалися під час «посижіння»етапу в поховальному ритуалі, коли до хати, де лежить померлий, сходилися люди. Це тривало протягом однієї-двох ночей ${ }^{17}$.

В опублікованих джерелах та літературі сьогодні знаходимо опис понад 30 різних ігор, які чинилися гуцулами під час «посижіння». Найбільш поширеною серед них була гра «грушка», назва якої подекуди заміщала поняття «посижіння». Також найбільш часто згадуються наступні ігри: «Коза», «Заєць», «Діди», «Жид купець», «Тягнення Бога», «Пекти гусака» ${ }^{18}$. Ігри починали парубки, участь у них брала в основному неодружена молодь, рідше - недавно одружені пари. На Закарпатській Гуцульщині вікова приналежність не мала значення ${ }^{19}$. Ігри зазвичай відбувалися у хоромах (довгих сінях) ${ }^{20}$, на дворі або ж у кімнаті, де лежав мрець. Якщо довіряти опису «посижіння» у книзі Петра ШекерикаДониківа «Дідо Иванчик», то «забави» могли відбуватися паралельно - як на вулиці, так і хоромах $^{21}$.

У першу чергу варто відзначити час проведення «забав при мерці». Якщо ж «посижіння» тривали протягом 1-2 діб, то в ігри молодь грала саме у ніч першої доби. Безперечно хронотоп «забав» чітко вказував на їхнє «чуже походження», використовуючи трансформацію бінарної опозиції «хаос/космос» на «ніч/день». Саме в нічну пору на Івана Купала можна було побачити персонажів потойбічного походження: бісів, чортів, упирів, відьом.

Значна кількість забав під час «посижіння» були спрямовані власне на заподіяння тілесної шкоди. Такі дії своїм семантичним навантаженням маркували проникнення «хаосу» у звичний для людей плин подій. До прикладу, у грі «Коза» хлопець перебраний у «козу» забігав до кімнати, де лежав померлий, і починав зачіпати присутніх «рогами», особливо дівчат і жінок ${ }^{22}$. Граючи у «Сороку», одна з дійових осіб мала зав'язані очі та йшла на заклики інших учасників дійства, водночас бючи учасників «посижіння» палицею, яку тримала у руках ${ }^{23}$. Під час «Млина» учасники гри били людей палицями по ногах, а також «плювали видџям (глядачам) в очі». Аналогічно такі ж антиповедінкові коди заподіяння шкоди бачимо й в іграх «Білиця», «Тешуть дуба», «Весілля з музиками» та «Галамбеза» ${ }^{24}$.

Окремо від цих ігор виокремлюємо ті, в яких побої наносилися тільки тим, хто брав участь у дійстві. Їхнє ритуальне значення крилося не стільки у демонстрації антиповедінки, а скільки у потребі отримання нових знань. Як зазначає українська

\footnotetext{
${ }^{16}$ Гузій Р. Похоронна обрядовість українців Карпат...

${ }^{17}$ Шекерик-Доників П. Рік у віруваннях гуцулів...

${ }^{18}$ Свєнціцький I., Гнатюк В. Похоронні голосіння... Шекерик-Доників П. Рік у віруваннях гуцулів... Шухевич В.О. Гуцульщина...

${ }^{19}$ Чернеляк I. Поховально-поминальні обряди українців Закарпаття...

${ }^{20}$ Сушко В. Уявлення про смерть і поховальні звичаї гуцулів...

${ }^{21}$ Шекерик-Доників П. Дідо Иванчік: роман...

${ }^{22}$ Шекерик-Доників П. Рік у віруваннях гуцулів...

${ }^{23}$ Шухевич В.О. Гуцулыщина. Ч. ІІІ...

${ }^{24}$ Свєнціцький І., Гнатюк В. Похоронні голосіння...; Шекерик-Доників П. Рік у віруваннях гуцулів...
} 
етнологиня О. Аксьонова, побиття є найпростішою маніпуляцією, що здійснюється 3 метою опановування чого не будь. Водночас побиття є одним із способів отримання нових знань ${ }^{25}$. Тому частина «забав при мерці» була способом згромаджень молоді отримати нові знання у період ритуального перебування в хаосі.

До таких ігор відносимо «Грушку», суть якої полягала в наступному. Молодь збиралася у коло, а один з гурту сідав посередині нього та закривав очі. Після цього один 3 учасників бив того, хто сидів всередині. Останній мав відгадати: хто саме його вдарив. Якщо виходило, вони мінялися місцями, якщо ж ні - далі залишався в середині й отримував побої ${ }^{26}$. Водночас ця гра має кілька своїх різновидів, серед них «На него», «Двірник і джурат», «Шишека», «Коса», «Лопатки» ${ }^{27}$ «Грушка» у контексті ритуального процесу похорону могла виконувати й ініціаційне навантаження для нового члена парубоцької громади ${ }^{28}$.

Як зазначено в етнографічних описах, нерідко такі ігри спричиняли багато сміху. На цю особливість звертав увагу митрополит Андрей Шептицький, який у своєму листі «До моїх любих гуцулів» писав: «Така “грушка”, як Ви ї̈ називаєте, дуже погана установа! Найперше тому, що не годиться сміятися в хаті, поки ще не поховають померлого» ${ }^{29}$. Проте якщо розглядати сміх не як «погану установу», а як елемент ритуального процесу, то можемо побачити, що він є інструментом виходу учасників дійства за межі наявного стану. Ритуал - це «священний час» у порівнянні 3 профанним, а сміх - «точка переходу» в інший хронотоп. Сміх виступає інструментом повернення до хаотичності ${ }^{30}$, своєрідного хронотопу, центром відліку якого стає мрець. Як зазначає українська етнологиня Марія Маєрчик, «зразком виходу з кризи для ритуалу є сакральний прецедент - міфологічний час світотворення з хаосу» ${ }^{31}$. Здійснення ритуальних дій, що змушують людей сміятися це спосіб повернутися до точки створення. Адже, як підкреслює румунський етнолог М. Еліаде, повторення космогонічних подій легалізує й унормовує подію у «профанному» житті, робить її реальною ${ }^{32}$.

Перебування у стані хаосу характеризується антиприродною трансформацією. Саме тому в «забавах при мерці» у гуцулів чітко простежуємо елементи переодягання. Символіка зміни зовнішнього вигляду криється в тому, що учасники ритуалу змінюють свої людські якості на протилежні. Саме в лімінальні періоди відбуваються метаморфози, які не притаманні у звичайному житті. Хлопці постають в образі дівчат і навпаки; тварини розмовляють.

\footnotetext{
${ }^{25}$ Аксьонова О. Ініціація через гру (за матеріалами українських дитячих ігор кінця XIX - початку XX ст.). М. Гримич (ред.). Народна культура украӥнців: життєвий цикл людини. Т. 1: Діти. Дитинство. Дитяча субкультура. Київ: Дуліби, 2016. С. 167-181.

${ }^{26}$ Шекерик-Доників П. Рік у віруваннях гуцулів...

${ }^{27}$ Свєнціцький I., Гнатюк В. Похоронні голосіння... Чернеляк I. Поховально-поминальні обряди українців... Шекерик-Доників П. Рік у віруваннях гуцулів...; Шухевич В.О. Гуцульщина. Ч. ІІІ...

${ }^{28}$ Детальніше про ініціаційні практики гуцулів можна прочитати у: Зубик Л. Маскулінні ініціаційні практики у гуцулів. Проблеми гуманітарних наук: збірник наукових пращь Дрогобищького державного педагогічного університету імені Івана Франка. Серія Iсторія. 2020. № 3/45. C. 346-363. DOI: https://doi.org/10.24919/23122595.3/45.203963)

${ }^{29}$ Шептицький А. До моїх любих гуцулів. URL: https://zaxid.net/do_moyih_lyubih_gutsuliv_n1492197

${ }^{30}$ Рейдерман I. Сміх як затвердження буття. URL: http://doksa.onu.edu.ua/article/view/211398

${ }^{31}$ Маєрчик М. Бінарна семантична опозиція «ТУТ» « «ТАМ» у конструюванні візії потойбічного світу. Родовід: наукові записки до історії культури України. 1996. Ч. 13. С. 3-10.

${ }^{32}$ Еліаде М. Трактат з історії релігій. Київ: Дух і літера, 2016. 520 с.
} 
Серед відомих нам «забав при мерці» можемо чітко виділити два типи візуальної трансформації учасників ігор. У першому випадку молодь переодягалася у зооморфних персонажів. У вищезгаданій «Козі» хлопець перевтілювався у козу, одягаючи на голову рукав сардака, в який вставлялася бартка, до верху якої чіпляли роги та бороду. Одягнувши цю конструкцію на голову, втрачаючи змогу бачити ${ }^{33}$. у грі «Жид купець» двоє хлопців імітували коня, на якому їздив єврей, а учасників «посижіння» зганяли до гурту, називаючи їх «телицями, коровами та бугаями» ${ }^{34}$.

Другий тип переодягання характеризується травестією персонажів. у грі «Діди» учасники переодягаються у старих чоловіка та жінку й імітують їхню мову та поведінку. В одному локальному варіанті під час гри «дід» і «баба» ставали перед мерцем і всіляко вихваляли його ${ }^{35}$, в іншому - зчиняли театралізовану сцену сварки 3 елементами приниження та побиття ${ }^{36}$. Також записаний варіант, де «дід» вбивав «бабу» та починав над нею голосити ${ }^{37}$.

В іграх «Млин», «Жид купець», «Вірмени» присутнє переодягання й у представників інших етносів, що проживали поруч з гуцулами ${ }^{38}$, а також наслідування їх поведінки ${ }^{39}$. Давно помічено, що в ритуалах як родинного, так і календарного циклу, персонажі інших етнічних меншин та етнографічних груп відіграють роль «чужого» ${ }^{40}$.

Безпосередні учасники «забав при мерці», відповідно, безпосередньо перебували у стані хаосу. Окрім нанесення побоїв і переодягання, вони частково втрачали свої символічні людські характеристики. У забавах головним елемінативним елементом була ритуальна сліпота, яка досягалася зав'язуванням очей чи одяганням на них головного убору. Символічну втрату зору зустрічаємо в іграх «Грушка», «На него», «Сороки», «Коза» «Двірник і джурат», «Піжмурки» ${ }^{41}$.

Окрему групу «забав при мерці» становлять ігри, що містять у собі молодіжний еротичний підтекст. Це водночас $є$ проявом антиповедінки, адже відкрите демонстрування відносин між хлопцем і дівчиною в українській культурі було табуйованим і засуджувалося. Натомість під час «посижіння» відкрито перед громадою відбувався обмін поцілунками між молоддю. Ба більше, якщо дівчина чи хлопець давали відмову, то їх привселюдно принижували.

Так, у грі «Пекти гусака» між учасниками дійства відбувався наступний діалог:

- Що робиш?

- Печу гусака.

\footnotetext{
${ }^{33}$ Шухевич В.О. Гуцулыщина. Ч. ІІІ...

${ }^{34}$ Шекерик-Доників П. Рік у віруваннях гуцулів...

${ }^{35}$ Шухевич В.О. Гуцульщина. Ч. ІІІ...

${ }^{36}$ Свєнціцький І., Гнатюк В. Похоронні голосіння...

${ }^{37}$ Кузеля 3. Посижінє і забави при мерци в українськім похороннім обряді...

${ }^{38}$ Шухевич В.О. Гуцульщина. Ч. ІІІ...

${ }^{39}$ Шекерик-Доників П. Рік у віруваннях гуцулів...

${ }^{40}$ Кметь В. Образ чужого і категорія непростих у системі демонологічних вірувань про українську відьму. Восьмі всеукраїнські наукові фольклористичні читання, присвячені професору Лідії Дунаєвській: матеріали науково-практичної конференції. Київ, 2009. С. 37-39

${ }^{41}$ Свєнціцький I., Гнатюк В. Похоронні голосіння...; Шекерик-Доників П. Рік у віруваннях гуцулів...; Шухевич В.О. Гуцулыщина. Ч. ІІІ...
} 
- А коли його спечеш?

- Коли масть потече.

- А коли масть потече?

- Коли та, а та, поцілує.

Після того як вказали на дівчину, вона була зобов'язана поцілувати «пана», який «пік гусака». Якщо ж відмовлялася - її насилу вимащували сажею ${ }^{42}$. В іншому варіанті гри право визначати, хто має поцілувати «королів», мали «вірмени» ${ }^{43}$. На Буковинській Гуцульщині «пекти гусака» могли паралельно дійству «Баба і дід» ${ }^{44}$. Аналогічна суть (поцілувати хлопця) була в іграх «Перстенець», «Огарчик», «Я завис» ${ }^{45}$.

Висновки. «Забави при мерці» у поховальному ритуалі гуцулів були основною складовою правильного здійснення ритуалу переходу. Ігри, в які грали під час спільного перебування біля померлого, були необхідним елементом у комплексі дій, що призводили до зміни статусу людини - із живого на неживого. Екстраполюючи цю дихотомію на опозицію «космос/хаос», учасники ритуалу символічно поверталися у первісний момент для того, щоб відтворити космогонію. Тільки таким чином особа могла легітимно та повністю змінити свій статус у свідомості людини та соціуму.

«Забави при мерці», як складовий елемент «посижіння», у цілому характеризуються своєю лімінальною семантикою. У традиційній культурі ритуальна «хаотизація» довколишнього простору, де відбувається головне дійство, здійснюється шляхом виконання дій, які у звичайний (профанний) часовий відрізок є недопустимими, табуйованими, а отже - викликають суспільний осуд. В умовах лімінальності ці дії навпаки - дозволені та не викликають обурення соціуму.

Велика кількість ігор (понад 30) свідчить про надзвичайну варіативність «забав при мерці» як у плані локальних особливостей традиційної культури, так і в контексті семіотизації дійства. Адже для чіткого маркування проявів «хаосу» необхідно було продемонструвати хоча б кілька його проявів. Такими типовими маркерами у похоронному обряді гуцулів були: хронотоп дійства, антиповедінка, травестія, сліпота.

Обов'язковою умовою проведення «забав при мерці» була нічна пора, яка є типовим часом здійснення ритуалів чи обрядодій, пов'язаних 3 потойбіччям. Саме ця умова давала можливість виконати інші «хаотизовані» дійства. у цей час люди, які прийшли на «посижіння» спостерігають «антиповедінку» молоді - сміх, глузування, еротизацію; травестію у тварин, які говорять, чи представників інших етнічних груп, що роблять свої справи; зазнають побиття чи приниження від дійових осіб забав і водночас - самі долучаються до них. Все це творить особливе середовище в окремо взятий відрізок часу та створює реальний ефект лімінальності кожного, хто знаходиться поруч 3 мерцем. Таким чином, використання вищезгаданих дій давало можливість гуцулам реально втілити символічність «повернення до хаосу», що дозволяло відтворити космогонію, а отже здійснити правильну зміну (перехід) статусу особи.

\footnotetext{
${ }^{42}$ Свєниіцький I., Гнатюк В. Похоронні голосіння...

${ }^{43}$ Кузеля 3. Посижінє і забави при мерци в українськім похороннім обряді...

${ }^{44}$ Кожолянко Г. Розваги та ігри у поховальному обряді буковинців...

${ }^{45}$ Кузеля 3. Посижінє і забави при мерци в українськім похороннім обряді...; Шухевич В.О. Гуцульщина. Ч. ІІІ...
} 


\title{
The Role of «Games Near the Cadaver» in the Ritual Process of Funeral in Hutsuls
}

\begin{abstract}
Annotation: «Games near the cadaver» - the component of so-called «posyginnya», what took place in first evening after person death. The same games while funeral rites observed in Croats, Serbs, Bulgarians, Moldovan, Romanians, Germans and other ethnic groups traditional culture. In the past, «Games near the cadaver» were spread on Ukrainian ethnic land, but started to go out of being in the first half of XX century. Nowadays, there are currently more than thirty games known in historical and ethnographic sources about Hutsuls. The most used game named «Hhrushka», as well as popular - were «Koza» (goat), «Didy» (grandparents), «Zhyd kupecz» (Jew merchant), «Tyahnennya Boha» (pull the rope), «Pekty husaka» (bake the goose). The purpose of the study is to overture to determine the role of «Games near the cadaver» in contexture cadavers status change ritual process. The research is conducted on the basis of ethnographic descriptions of the end of the XIX - first half of the XX century and historiography. The research methodology is based on structural-semantic, semiotic and typological analysis principles. Games determination put through in context of rite of passage. Conclusions. In Hutsuls funeral rite, «games near the cadaver» were a compulsory part of the unerring status change ritual process. During the "posyginna», the rite characters symbolically return to creation time, extrapolating binary opposition live/dead to cosmos/chaos. In traditional culture, this is one way to change the person status legitimately and without effect for people and society.
\end{abstract}

As an important part of the «posyginna», the "games near the cadaver» in general have a liminal semantics. Chaos ambience impact created by taboo actions, which in profane time cause public condemnation. But, being in «limen», the participants have the right to taboo or amoral things, which do not cause disapproval only in this period.

The large set «games near the cadaver» evidence about the need of different semiotic instruments for denotation being in chaos. The ritual demanded a composition of symbols that in reality embody the liminality of the process. In Hutsuls, the rite characters usage chronotope, anti-behavior, travesty, sightliness for the purpose of mark permeation of chaos.

Night time was the main term for the "games near the cadaver». This is the typical period for all the rituals associated with the after world (let's compare divination at Saint Andrew's Day). This condition was a gateway to other signs of chaos. During the «posyginnya» occurred actions that cause laughter and jeer: lads and wench disguised as animals or person of another ethnic group; bachelors forcibly forced to kiss girls and women; viewers has been hurt and humiliated, but instead joined the games. All this part of «games near the cadaver» conditioned real liminal effect for all funeral participants. In this manner, playing near the cadaver, people performed the next step in the ritual process of status change.

Keywords: rites of passage, funeral rites, games near the dead, night near the dead, «hrushka», hustsul's 